\title{
Diseases of the Douglas Fir in Britain.
}

$\mathrm{A}^{\mathrm{S}}$ is often the case with exotics, there have been one or two scares on the subject of diseases in connexion with the Douglas fir plantations in Britain. A fungus attack reported in a young plantation, when investigated, proved to be caused by an undescribed species of Phomopsis (P.Pseudotsuga Wilson). Then a species of Chermes (Chermes Cooleyi) appeared in several parts of the country. A recent leaflet (No. 18) issued by the Forestry Commission, deals with a disease new to Britain, the Douglas fir leaf-cast disease (Rhabdocline Pseudotsugo Syd). The disease is common on the Douglas in the United States, but until within the last few years it had not apparently been noticed on the east of the Atlantic. It has been found on the blue form of the Douglas fir (Pseudotsuga glauca) and on the interior dry belt or Fraser River form ( $P$. Douglasii var. caesia). Recently it has been also observed on the green Douglas ( $P$. Douglasii $)$. This fungus occurs on all forms of the Douglas in the United States, and occasionally becomes epidemic for a season or so. It usually only infests young trees, but attacks larger trees growing on poor quality soils.

Infested needles develop blotches on the under surface during the winter, and at a later date tissues of the leaf on the upper surface, directly above, turn a yellowish brown. By early spring these areas turn a purplish brown, which, contrasted with the green unattacked part of the needle, give the infested foliage a mottled appearance not unlike the resultant mottling produced by Chermes Cooleyi. In the latter, however, the presence of the small secretions of white wool on the under surface of the needles serve to distinguish this attack. In the case of the fungus, the mycelium is developed in the leaf and does not pass back into the shoot. About March the hyphæ become numerous on the lower surface of the leaf just beneath the two bands of stomata in the discoloured spots, and it is here that the fructifications are formed. In May the epidermis ruptures, disclosing an orange-coloured layer which bears the spores. Spores are liberated at the time the buds are opening, and infection takes place shortly afterwards on the young needles. Infected needles fall at all seasons of the year. Trees attacked for several years by this fungus may be almost entirely defoliated and may die.

The green Douglas appears to be the least subject to this fungus. So far, the disease has been reported from Peebleshire and from several counties in the south of England. At present it is deemed impossible to suggest any definite remedy, but, in the case of an attack appearing on a few young trees only, the advice is tendered that they should be removed and burnt. In the nursery, spraying with a solution of soap and Bordeaux mixture as practised in the United States is recommended.

In the case of infestations, such as those here mentioned on the Douglas, the real solution would appear to rest on sylvicultural considerations. The planting of pure blocks of rapidly growing exotics is, in many parts of the world, to court disaster in the long run, in one form or another; more especially when the behaviour of the exotic from the sylvicultural point of view, in its new environment, is by no means well understood.

\section{Building Research. ${ }^{1}$}

THE poet Cowper wrote the well-known couplet, "Knowledge is proud that he has learned so much ; Wisdom is humble that he knows no more," and it was Tennyson who said, "Knowledge comes, but Wisdom lingers." These statements are indeed true of building science. The past centuries have witnessed an ever-increasing store of knowledge, wherein precedent, with the natural improvements added for the day current, shows the accretion of knowledge, though not necessarily an accretion of wisdom.

The work of the Middle Ages was largely empirical in nature, though we of to-day would hesitate to deny the wisdom of the ancients of Assyria, Egypt, Greece, and Rome in their palmy days of building activity. Forgetting for the moment the simpler constructive science involved in trabeate architecture, how else than by superior wisdom can we account for the survival of the magnificent relics to the present time -a survival that would have been far less mere relics had it not been for the fortuitous effects of bombardments and the criminal vandalism shown in using some of these buildings as mere quarries ?

Though the monks may be credited as having been in the possession of a large amount of useful scientific knowledge in regard to building, as their stately cathedrals show us to this day, yet this knowledge lacked that admixture of wisdom which would have secured to their creations the same defiance of time as appertained to the earlier art. They could calculate to a certain degree the structural basis of the vaulting and groining, so as to promote the attainment of their aim, but the inadequacy of the results is made too painfully evident in these latter days. The poor quality of the stone, the inefficient counterforts and sundry other defects, entail the vast expenditure so

1 " Report of the Building Research Board for the Period ended 31st December, 1926." (London: H.M. Stationery Office, 1928.) 2s. frequently witnessed. Even after making allowances for altered conditions consequent upon tunnelling beneath the surface for railways and sewers and the deep excavations for commercial purposes, as well as allowing for the pollution of the atmosphere by reason of industrial processes, yet the charge of inadequate wisdom is justified in its entirety.

A welcome is therefore to be accorded to the present (if somewhat overdue) activity on the part of the Government, whereby scientific research into the capacity and quality of building materials is being undertaken; twofold in its nature, namely, curative research for the purpose of remedying accrued defects, and prophylactic research, which is wisdom in the highest degree, whereby preventive measures may be adopted in time.

The first Report of the Building Research Board, appointed by the Department of Scientific and Industrial Research, has recently been issued; brief as is the period during which the Board has been in existence, there is ample evidence of its utility.

The Board divides its operations into two main sections, $(a)$ general research and $(b)$ intelligence and special investigations; a reproduction of its 'labour tree' will best conduce to an appreciation of the method pursued :

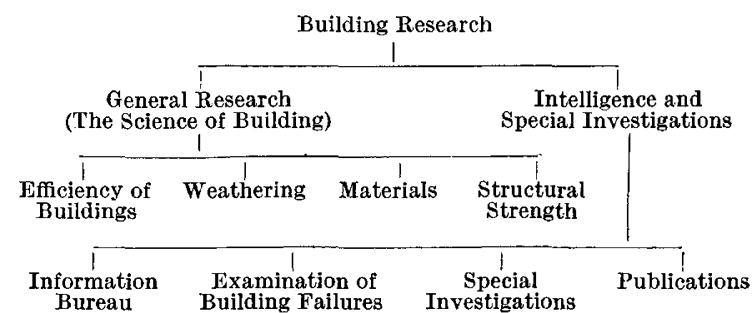

No. 3047, VoL. 121] 
The subject of weathering has been considered from the various aspects of chemical attack (including solvent action of rain); biological attack, bacteria, lichens, etc.; movements due to temperature and moisture changes; and frost.

It is somewhat on the lines of the bismuth meal, when we note how investigators employ the method of impregnation of stones with coloured resins as a means of tracing the porosity channels of the various stones. Sections of decayed samples upon examination thus enable the formation of sulphates to be studied. In research upon the transmission of chemical solutions as preservatives, it has been demonstrated that the crystallisation induced by evaporation from the face of a wall so impregnited is often a cause of decay; when perished mortar joints have been made sound, evaporation will, in following the line of least resistance, issue from the stone itself, and hence the decay.

Further, it was found that aerobic bacteria rarely penetrate more than an inch below the surface; research into anaerobic bacterial activity has yet to be undertaken. The Board considers, after investigation, that there is no reason to believe that beetles cause decay in stonework; they use the already decayed stone merely as a home, not as a nidus.

Cement and concrete have claimed the Board's attention, and it is shown that the rapid-hardening Portland and high alumina cements are far more impermeable than the ordinary Portland cement. It is shown, too, why the cracking in the cement should be prevented; for if water cannot penetrate the material, then soluble salts cannot be washed out, nor can the steel embedded in reinforced concrete be attacked.

The Board expresses its belief that the deleterious action of frost is not so noticeable in Great Britain as it may be elsewhere. A series of freezing tests upon stone, brick, and tiles indicated general agreement with those of Kreüger in Sweden, where, however, frost is often very disintegrative in its action.
The behaviour of stone preservatives in a town atmosphere is being tested with a series of stone piers, treated and untreated, some with 'dished' tops, others with weathered tops; they are set upon the roof of a Government building in London. Also an illuminating set of experiments has been conducted upon the relation between the wet and dry strengths of bricks and stones.

Most of the Board's work is carried out at its station at Watford, but some investigations are undertaken elsewhere, including the National Physical Laboratory, where an interesting test is being conducted regarding vibration in buildings and fatigue in materials, and also the effect of wind pressure on roofs. The subject of wind pressure upon bridges is also being investigated.

Table 4 is illuminating regarding the diminution of tensile strength which so frequently takes place in neat cement with increasing age; whereas the compressive strengths, shown in Table 5, indicate fairly steady increase. Incidentally, it may be remarked that, later on in the Report, there is some confusion in numbering the tables.

A very valuable branch of research deals with acoustics, hitherto so largely a matter of empiricism in practice. Architects and engineers may now, with some assurance of satisfaction, seek the advice of the Board in this respect; a notable case in point is the series of acoustical experiments undertaken for the Government of India for the new buildings at Delhi.

Limits of space preclude adequate justice being done here to the many or to any of the activities of the Board. We must rest content with a mere brief schedule of such matters as condensation, waterproofing, repairs to old painted ceilings, etc.; the use of wood-cements, wall boards, plaster substitutes, and asphalte; investigation into dry rot, etc. The survey is all too briof regarding an undertaking of which the ramifications are numerous and the labour is indefatigable.

\section{Plankton Migrations.}

$\mathrm{D}^{\mathrm{B}}$ R. KENZO KIKUCHI, in a paper entitled "Notes on the Diurnal Migration of Plankton in Kizaki Lake" (Journal of the College of Agriculture, Imperial University of Tokyo, vol. 9, No. 3, Aug. 1927), recounts some interesting results arrived at by studying certain species in the plankton of Kizaki Lake in the Nagano Prefecture. The pump method was employed, about fifty litres of water being pumped from different depths at periodic intervals and strained through a plankton net. The number of each species was then counted and recorded. These included Cladocera, rotifers, rhizopods, and dinoflagellates, the Cladocera and copepods being specially studied. The lake lies at an altitude of 764 metres, the greatest length being three kilometres, the greatest breadth one kilometre. It is bordered by mountains and plains, and its greatest depth is 29 metres. The temperature ranges in August from $6^{\circ} \cdot 2$ near the bottom to $26^{\circ} \cdot 6$ at the surface, and in December from $5^{\circ} \cdot 6$ to $8^{\circ} \cdot 2 \mathrm{C}$.

The diurnal migration was found usually to be most distinct in those species living at depths less than 10 metres. Thus Polyphemus pediculus and Bosminopris deitersi occur at maximum at a depth of 2 metres in the daytime and tend to come nearer the surface at sunrise and sunset, migrating downwards during the day and night. Their maximum near the surface is reached before midnight, after which there is a slight tendency to move downwards.
Daphnia longispina, living at about 10 to 15 metres during the day, shows no tendency to migrate upwards in the summer, but may move downwards at night. In December, however, when it is spread out from the surface to near the bottom, it shows a slight movement upwards at night, the temperature in the upper layers being lower at that time.

Some interesting observations are made on the various stages from nauplius to adult of the copepod Diaptomus denticornis, which migrates upwards at night to attain its maximum at the surface before midnight. In August it was found that the younger the forms the nearer they are to the surface during the day and also the earlier do they reach the surface at night, whilst in the morning they leave the surface later than the older stages. Thus the young stages stay for a longer period near the surface than the older stages. In December there was no diurnal movement in the young forms which had a vertical range from the surface to 10 metres, although the adults still migrated towards the surface at night.

The dinoflagellate Ceratium hirundinella was found to range from 2 to 10 metres and to be especially abundant at 5 metres. It moves upwards at night and reaches a maximum at the surface shortly before sunrise.

Most of these migrations show better in August, the number of specimens falling considerably in December. 